\title{
Historical Intimacy in Malay Urban Core Configurations: A Comparative Analysis
}

\author{
Illyani Ibrahim ${ }^{1}$, Shireen Jahn Kassim², Alias Abdullah ${ }^{3}$ \\ ${ }^{1}$ International Islamic University Malaysia, Kulliyyah of Architecture and Environmental Design, Department of Urban and Regional Planning \\ e-mail: illyani_i@iium.edu.my \\ ORCID iD: https://orcid.org/0000-0001-8154-5579 \\ ${ }^{2}$ International Islamic University Malaysia, Kulliyyah of Architecture and Environmental Design, Department of Urban and Regional Planning \\ e-mail: puterishr@iium.edu.my \\ ORCID iD: https://orcid.org/0000-0003-1139-5485 \\ ${ }^{3}$ International Islamic University Malaysia, Kulliyyah of Architecture and Environmental Design, Department of Urban and Regional Planning \\ e-mail: dralias@iium.edu.my \\ ORCID iD: https://orcid.org/0000-0001-9139-2529
}

Submitted: 21 June 2019. Accepted: 19 April 2020

\begin{abstract}
This paper analyses the historical pre-Colonial configurations of a series of urban cores in Malay sites along the Straits of Melaka. The objective of this research is to identify the pattern and variations of each pre-Colonial royal urban core from the perspective of urban design principle such as "intimacy" and "walkability," which can affect in a long term sustainable parameters such as the reduction of "urban heat island". This traditional character is increasingly disappearing due to urbanisation. There is a difficulty to reconstruct the urban core of these case studies because of their past layouts' degree of organic character, particularly in terms of randomness. This paper argues that such configurations reflect the degree of "intimacy," which was ruptured during the Colonial eras. Patterns were identified using available maps and lithography related to the case studies. The findings indicate that the Malay royal urban core does obey the urban design principles of intimacy and walkability. The "intimacy indices" for a historical Malay city are as follow: distance from palace to mosque (170 metre), padang/open spaces (130 metre), settlement (310 metre), market (195 metre), and aristocrat houses (60 metre). This finding can be used to inform the baseline for the preparation of the Malay principles guidelines.
\end{abstract}

KEYWORDS: Preservation; Built forms; Urban design; Malay character of cities; Redevelopment; Organic patterns.

Citation / Cómo citar este artículo: Ibrahim, Illyani; Kassim, Shireen Jahn and Abdullahm Alias (2020) "Historical Intimacy in Malay Urban Core Configurations: A Comparative Analysis" Culture \& History Digital Journal, 9 (2): e020. https://doi.org/10.3989/chdj.2020.020

RESUMEN: Intimidad Histórica en las Configuraciones de los Núcleos Urbanos Malayos: Un Análisis Comparativo.Este artículo se centra en el análisis de las configuraciones precoloniales históricas de una serie de núcleos urbanos en localizaciones malayas a lo largo del estrecho de Malaca. El objetivo de esta investigación es identificar el patrón y las variaciones de cada ciudad real precolonial desde la perspectiva de principios del diseño urbano como "intimidad" y "viabilidad peatonal", que pueden afectar y reducir parámetros de sostenimiento a largo plazo en ciudades tropicales como el "efecto insular de calentamiento urbano". Mientras este carácter tradicional desaparece progresivamente debido a la urbanización moderna, la dificultad está relacionada con el grado de carácter orgánico o aleatoriedad en el plano pasado de estos núcleos urbanos tradicionales. Se argumenta que tales configuraciones reflejan un grado de "intimidad" que fue quebrado durante el periodo colonial. El principal resultado es que la ciudad real malaya obedece al principio de diseño urbano de una "intimidad" y "viabilidad peatonal". Los "índices de intimidad" para la ciudad histórica malaya son los siguientes: distancia del palacio a Masjid (170 metros), Padang/espacios abiertos (130 metros), asentamiento (310 metros), mercado (210 metros) y casas aristocráticas (60 metros). Estos descubrimientos pueden ser usados como referencia para la preparación de las principales guías malayas. 
PALABRAS CLAVE: Preservación; Formas de construcción; Diseño urbano; Características de las ciudades malayas; Remodelación; Patrones orgánicos.

Copyright: (C) 2020 CSIC. This is an open-access article distributed under the terms of the Creative Commons Attribution 4.0 International (CC BY 4.0) License.

\section{INTRODUCTION}

Traditional cities hold certain characteristics due to the slow evolution of the physical elements that are distinctive from the modern forms. It can be argued that although these urban forms arose from organically-driven factors and parameters, the evolvement of their humanistic planning reflects the intrinsic character of South East Asian culture and population. Such characteristics can be discerned by comparing the difference between the urban configurations of Asian and European locations, or even more significantly, before and after the Colonisation era in South East Asia. In these Asian centres, the events of tumultuous nature have changed such pattern irrevocably hence the future growth of these settlements. One of the key parameters that have changed were communality or even "intimacy" within the centres of these settlements. Until the present times, the Asian urban centres lack the roots and identity grounding as found in European heritage cities.

It is argued that many of the urban forms in Europe were preserved by durable materials, which can be sustained across time. Many of the tropical Asian remnants, however, have been decimated without a trace. These patterns, including the centres of urban sites, contain certain traditional urban design principles that had gone through a process of being ruptured by external factors. The notion of intimacy and community arising from urban principles and features, such as courtyards, was then imported from external sources, such as Islamic planning. Yet, the features lack the rootedness and identity from the region.

Urban spaces are often described as "all types of spaces between buildings in urban core and other localities as urban space. Malay urban form constitutes several elements of urban form such as fort or fortification or a stockade and was the administrative centre for the Malay rulers during the splendour of the Malay Kingdom traditional rule" (Harun \& Jalil, 2014). The author, Harun \& Jalil (2014) also underline the following characteristics of a Malay urban form: (i) the location of the Malay forts being close to rivers and hills; (ii) a mosque being the essential landmarks in the city centre; (iii) the palace being the centre of governance and built overlooking wide open spaces or squares.

Traditional royal and builders were clearly involved in "urban planning," and their cities were "planned" settlements, following common sense notions of planning (Smith, 2007). The author further explained that most ancient cities are classified as "unplanned" in the literature on historical urbanism. The city planner of these urban cores is the rulers and noble person. The determination of a city centre or the area of an old town mostly still refers to an open field (padang) (Sunaryo, 2013). A padang plays an important role as a connection between the royal and the settlements. Sunaryo's study sought to understand the interaction between the elements of a traditional urban space. The close distances between spaces indicate the closeness of the royal and the people, who regularly moved within these spaces.

The term Malay includes the use of a particular culture, language, and thought. The Malays are an ethnic group who live in the Malay Archipelago. Malay is also defined as an ethnic group who dwelled in Southeast Asia and its neighbouring islands (Winstedt, 1934). Malays are an Austronesian ethnic group from the Malay Peninsula, eastern Sumatra, and coastal Borneo-the areas also known as Malay world. In fact, the term Malay has been much discussed by many scholars. The administration of Malays is usually headed by a sultanate or sultan, who is responsible for decision making and tax collecting. The sultan was then supported by a temenggung (police), a bendahara (prime minister), a laksamana (navy commander), and a syahbandar (port authority). In the fifteenth and sixteenth centuries, the term Malay appeared to have been used primarily in reference to the Melakan Malays. By the seventeenth century, however, the term Malay began to be used as it is today.

One of the characters of a vernacular settlement and those evolving into traditional cities is "intimacy". Intimacy was first revealed by philosopher Martin Heidegger as a man's "rapport with things" and mentioned as "nearness" (Dekkers, 2011). Here, "nearness" is used to describe the intensive relation between "man" and "thing". Factors such as local climate, cultural tradition, topography, blood, or social relationship are the basic conditions of the man. The relationship between the social and the spatial is an interactive one, in which people make places and places make people (Borden, Rendell, Kerr, \& Privaro, 2001). The relationship between individual and place acquires ritualistic characteristics.

While such parameters of intimacy and walkability can be physically defined as nearness or short distances, the inherent characteristic of the Malay world is the link between the public places, such as the palaces and the mosque. Before Colonisation, a palace was an accessible institution and had grounds which had evolved before the advent of a private car. By understanding the urban forms of the past and delving into the character of the traditional city in the Malay world, certain discerning characteristics can be identified. The concept of space intimacy within a community created social sustainability among all types of social level (Abdul Aziz \& Idid, 2010). The Malay society, in particular, has a preference for community intimacy rather than privacy (Yahya, 1998).

Yet, due to the fragile nature of the architecture (constructional landscape, ecological and local material found 


\begin{tabular}{|c|c|c|c|c|}
\hline & & Acheh & Alor Setar & Langkat \\
\hline \multirow[t]{2}{*}{1400} & 1500 & 1600 & 1700 & 1800 \\
\hline & Melaka & $\begin{array}{c}\text { Kuala } \\
\text { Kangsar }\end{array}$ & $\begin{array}{c}\text { Kuala } \\
\text { Selangor }\end{array}$ & Kota Bharu \\
\hline
\end{tabular}

Figure 1. Timeline for the royal sites.

in these tropical sites in tropical Asia), many of the attributes that characterised the local nature and phenomenology of these urban forms have disappeared. Such attributes and forms are increasingly being replaced with modern structures of concrete, asphalt, and steel, which are not only culturally alien, but environmentally devastating in a long term. Hence, the patterns of the past must be re-evoked and documented within the current modernisation processes, so as to prevent the identify from being permanently erased.

An urban form is characterised by a very localised scale, from the building materials to a broader scale, such as housing, street, and the spatial arrangement of such city. This study uses the element of urban form to explain the early principle of an urban core. Sunaryo (2013) explained that market, padang, palace, and masjid are the four main elements of principle in the early formation of the city. A fort is also one of the royal elements of the safety of the urban core itself. Another element of enclosure is formed by lining the street with unbroken building fronts of roughly equal height. The buildings become the 'walls' of the outdoor room, the street and sidewalks become the 'floor', and if the buildings are roughly equal height, the sky projects as an invisible ceiling (Smith, 2007). The building to building should not exceed the building heights to maintain a comfortable feeling of enclosure.

This study was intended to reconstruct the character of the local urban form. Thus, this paper focuses on the cultural urban patterns of urban forms in different sites of alam Melayu and areas along the Melaka Straits, specifically on "intimacy" and "walkability," by using historical documents and drawings, among others.

\section{METHODOLOGY}

The study was conducted by analysing old maps, historical documents, lithographs, and drawings from the past. Following a historical review of these sites, their overall brief patterns were identified. The key elements, including distances from key buildings, were also measured. Spatial configuration refers to the spaces that are arranged by a spatial system. These spaces are linked, creating a system that can capture the qualities of a traditional urban core by examining its space system. Some of the space systems are gridded; some are organic; and some have irregular geometry, among others. By using the space system, the sociocultural aspects of the case studies can be understood. A western traditional settlement usually has a gridded geometry, whereas a Malay traditional settlement is characterised by irregularity and organicity.
The royal sites were identified as the case studies for this research: Aceh (sixteenth CE), Kuala Kangsar (sixteenth CE), Kuala Selangor (seventeenth CE), Kota Bharu (eighteenth CE), Langkat (eighteenth CE), Alor Setar (seventeenth CE), and Melaka (fifteenth CE). An initial historical review of the above sites was undertaken to understand their historical and cultural backgrounds. The urban configurations were used to construct the Malay urban cores for the analysis of intimacy and walkability.

Figure 1 shows the timeline for the royal sites of the selected case studies. The glory of Melaka began in the 1500 s as a rich and powerful Muslim sultanate in archipelago. However, the town was taken over by Portuguese in 1511 and again by Dutch in 1641. After the fall of Melaka as an international trading port and a centre for Islamic learning and dissemination, the traders then moved to Aceh, which then replaced Melaka as another centre of for Islamic dissemination. In the same timeline, Kuala Kangsar, Perak, was opened by Sultan Mansur Syah as another urban core. Sultan Mansur Syah inherited his crown from his late grandfather, Sultan Mahmud Syah from Melaka ${ }^{1}$. Another urban core, Kuala Selangor became another royal kingdom under Sultan Salahuddin ${ }^{2}$. Alor Setar then became another urban core located at the northern part of Malay Peninsula, and the town was then found by the ruler Sultan Mohammad Jiwa Zainolabidin. Langkat, which was located at northernmost regency of North Sumatra, was another royal urban core which includes a formal Islamic institution in the South East Asia. The urban core of Kota Bharu was founded by Sultan Muhammad II around 1800s.

\section{Traditional Urban Configuration of Bandar Aceh}

The historical centre of Aceh sultanate was located at the westernmost point of the Indonesian archipelago (northern tip of Sumatra). This area was a meeting point of traders from the Western and Eastern Asia countries. The location of the harbour was strategic: it was a trading point along a shipping route that entered the Straits of Melaka. In the late $1500 \mathrm{~s}$, the sultanate of Aceh was the most powerful Islamic kingdom in Southeast Asia until it was known as Serambi Mekah. Figure 2 shows the spatial configuration of Aceh during seventeenth CE. The base map was gathered from Reid and Ito (2016), and the other elements are portrayed by comparison with the Florence map (Archiple

Sultan Mahmud Syah was the last sultan of Melaka. After Melaka was destroyed, his son Sultan Muzaffar Syah was invited to rule Perak who then had a son named Sultan Mansur Syah.

2 Sultan Salahuddin was the first sultan of Selangor. 


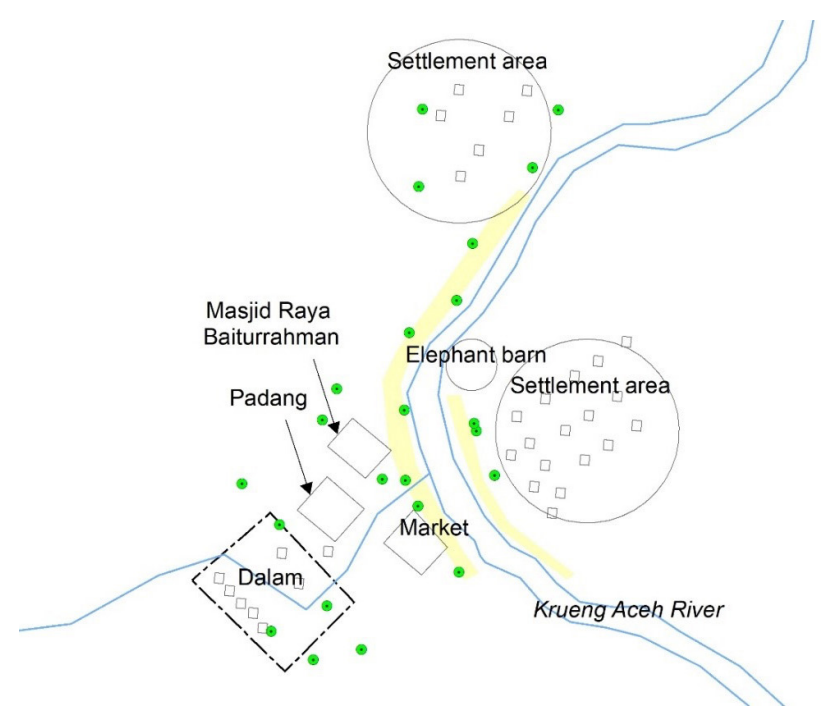

Figure 2. Traditional urban configuration of the Aceh Sultanate in the seventeenth CE.

57, 1999) (Note that the Florence map [Fig. 3] is not in scale.)

The dalam and its adjacent open spaces (medan khayyali), the great mosque (masjid raya), and the market were stable over two centuries (Reid \& Ito, 2016). The site of the royal enclosure, or dalam, was adjacent to Medan Khayyali with a river in it. Dalam, shown as the dotted black line in Figure 3, was the physical feature. The fort, in the rectangle area, acted as the most important administration place.

Masjid Raya Baiturrahman (the Grand Mosque) is located at the north direction of dalam and was built during the reign of Iskandar Muda in 1612. The wide padang (open spaces) are located near to the dalam of the king's palace, particularly for meeting and gathering with the rakyat. In the Florence map, those features that include the dalam are the two palaces, the customhouse, the two mosques, the laksamana's house, and the open spaces. Dalam is a complex used as the king and royal family's

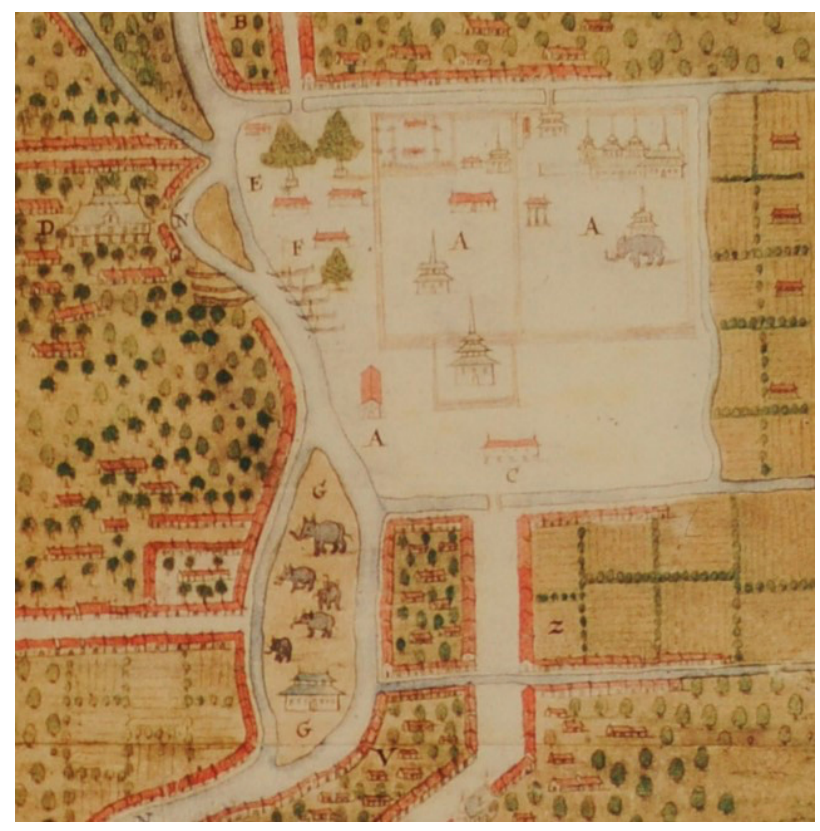

Figure 3. Dalam, inside the fortified during the Aceh sultanate era, which had a strong presence of elephants and boats. This map was drawn by a Dutchman in 1645 .

(Source: Reid and Ito, 2016).

residence and administrative centre. The laksamana plays a role as the panglima dalam who was in charge of the national security, and his house was located at the main entrance to the royal centre (Reid \& Ito, 2016). The original royal mosque had a multi-tiered thatched roof typical of an Acehnese architecture. The people would walk near to the river (yellowed colour) (Figure 2) as all of the public spaces were located near to it. The strategic location of the trees (green points) (Figure 4) made the facility favourable to be walking spaces (light yellow colour) under shaded trees. The shape of the padang is a large rectangle square where the interaction between the royal and people usually took place.

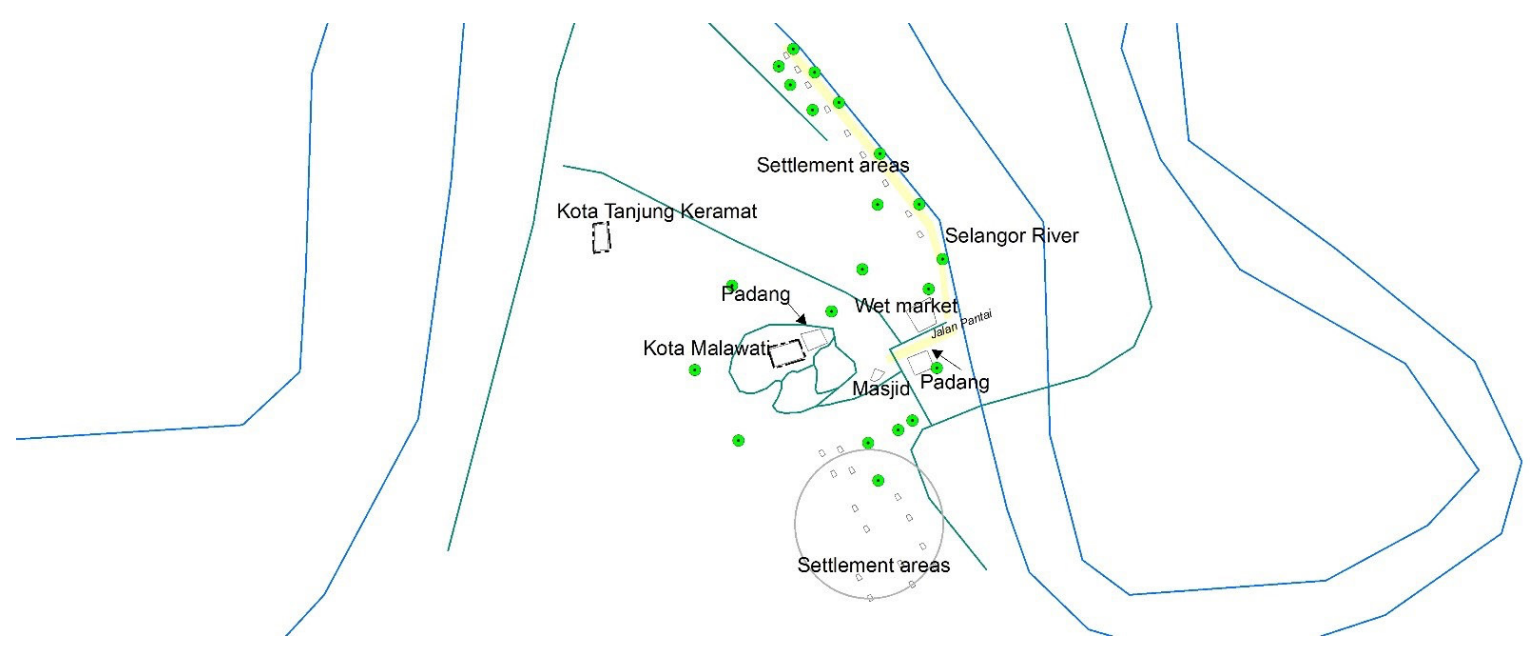

Figure 4. Traditional urban configuration of Kota Malawati in the seventeenth CE. 


\section{Traditional Urban Configuration of Kuala Selangor}

Kota Malawati is located at the top of the hill about 400 metres from the Selangor River, facing the coastal area at the west direction. The high ground allowed the monitoring of the ships that passed by the Straits of Melaka. The centre has distinctive archaeological remains of two forts built under the reign of the first sultan of Selangor, Sultan Salahuddin (1756-1770). The settlement of Kuala Selangor had become an administrative centre and stronghold of the Malay kingdom of Selangor during the period (Nasir \& Teh, 1997).

The fort was renovated by Sultan Ibrahim (1770 1826), the second sultan of Selangor. The fort is rectangular in shape. The fortification wall of two-metre high, was made of rough-hewn stones available locally (indicated by the dotted line Fig. 4). The approximate size of the fort is $74 \mathrm{~m} \times 30 \mathrm{~m}$. The gateway was located on the east side facing Sungai Selangor. The other fort, known as Kota Tanjung Keramat, is located on Bukit Tanjung Keramat, formerly known as Dutch Hill. Kota Tanjung Keramat is located next to Bukit Malawati. Figure 5 shows the urban configuration of Kota Malawati, Kuala Selangor.

There are padang located opposite to Kota Malawati. At the lower elevated regions, the wet market was located close to the river, which acted as the main transportation during those days (Fig. 5). The historical masjid (mosque) site is located on the existing mosque that can be seen today, at the foothill of Bukit Malawati. Jalan Pantai was used at the padang (open spaces), which was an area for official parades and games during those days. A small jetty was available for those who wanted to go fishing and ride along Sungai Selangor by using a sampan. These local streets formed a second level of the route network by increasing accessibility to the small urban core. About two kilometres from Kota Malawati is the location of Kota Tanjung Keramat. The people preferred to walk

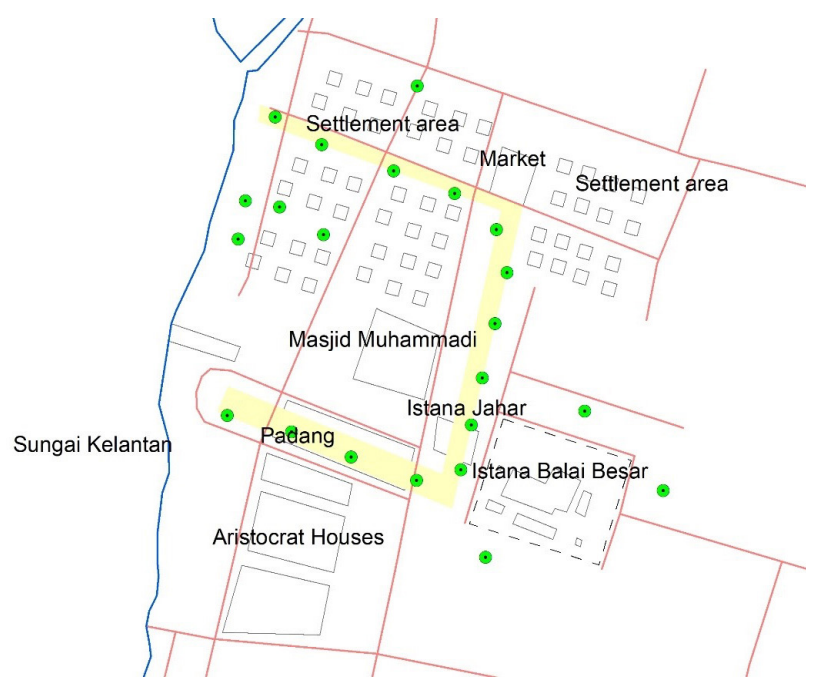

Figure 5. Traditional urban configuration of Kota Bharu in the eighteenth CE. nearby the river (indicated by the walkability lines of light yellow polygon in the urban configuration). The fort and settlement are within a walkable distance and are differentiated only by different elevations. The mosque seems to be the link between the royal compound and the settlement areas.

\section{Traditional Urban Configuration of Kota Bharu}

Located at the head of Sungai Kelantan, Kota Bharu is the fort that replaced Kota Kebun Mesra which was constantly sunk by Sultan Muhammad II during a flood. The site of the fort and the palace still remained until today (Abdul Halim Nasir, 1990). Istana Balai Besar was the main administrative centre of the state. The sultan made the Istana Balai Besar his residence, and Istana Jahar was used for other purposes.

Figure 5 shows the urban configuration of Kota Bha$\mathrm{ru}$, Kelantan. The palace has a courtyard and a gateway, which implies that defence was an important element of the royal areas. The palaces in Kelantan are close to the mosque. The distance between Masjid Muhammadi and Palace Balai Besar (built in 1845) is 200 metres. One of the features is the padang elongated to the river. This spatial relationship implies that the open spaces were a place for the sultan to have a meeting or gathering with the rakyat.

The old settlement and market in Kota Bharu are located in front of the river. The administration areas were found to be closely located to the mosque, a character that follows one of the Islamic guidelines explained in the literature review. Most of the mosques are located near to the palace of the sultan and the local village. The location was as such to make it easy for the sultan to travel between his palace and the villagers, as walkability indicated in light yellow colour. The settlement indicates the importance of the establishment of a fort or palace as decided by the ruler and the dependency of the villager towards the ruling of a sultan.

\section{Traditional Urban Configuration of Tanjung Pura, Langkat, Sumatera}

The Langkat region is also known as Hamparan Perak, Sumatera, due to its proximity to the state of Perak across the Straits. It was built when a minister called Dewa Shahdan escaped from Aceh in 1568 (Windari, 2017). Langkat was named after a tree of a well-known Malay fruit called Langkat, which was found at the brink of the river Langkat. Until today, Langkat is known as the literary centre of the Malay world, with forms that recall an essential Malay character, such as the typical bumbong panjang roof. Yet, the roof is inserted with a multi-tiered roof that form a characteristic of the Nusantara form with its layered structures of tropical openings. Istana Darul Aman was infused with the various elements of Arab Islamic origins. At present, only the entrance gate of both palaces still remain in front of Jalan Tengku Amir Hamzah, as the signs of the existence of these two palaces on the site. 


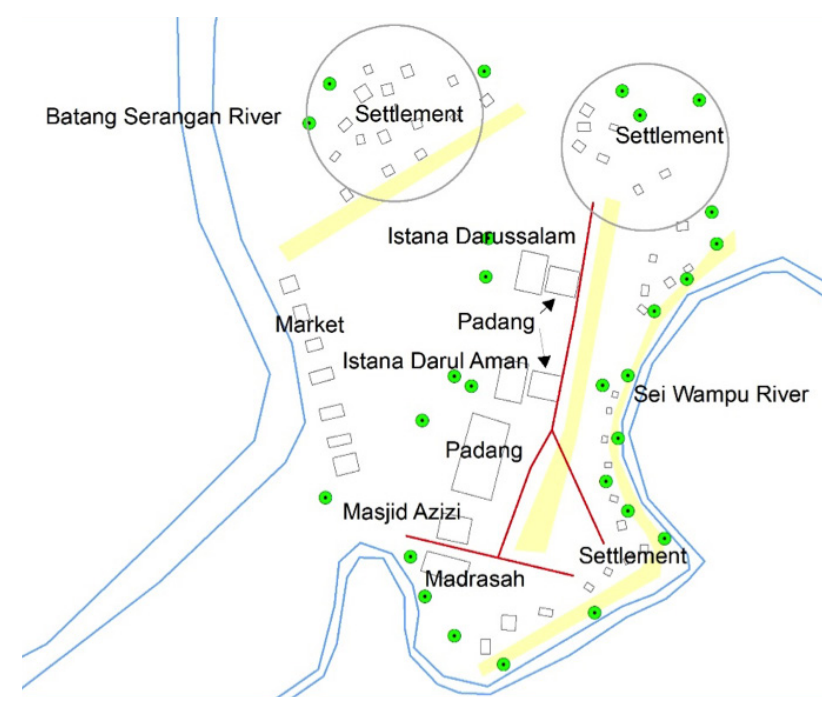

Figure 6. Traditional urban configuration of Tanjung Pura, Langkat, Sumatera in eighteenth CE.

Figure 6 shows the urban configuration for Tanjung Pura, Langkat, Sumatera. Langkat has two palaces: the earlier palace was Istana Darul Aman and the later one was Istana Darussalam. Istana Darul Aman was built in 1860 by Sultan Musa. The second palace, Istana Darussalam, was built since 1897 by Sultan Aziz, and was demolished during the Social Revolution in March 1946. Masjid Azizi, which still exists until today, is located opposite to Istana Darul Aman. The urban configuration shows that padang is located between Masjid Azizi and Istana Darul Aman. This palace, however, has its own padang located opposite to it. The location of Istana Darussalam is quite far from Masjid Azizi compared to the earlier Istana. Istana Darussalam has its own $p a-$ dang. The padang is that located between the mosque and Istana Darul Aman, and was a place for the people to gather for any occasion needed. Another padang in front of the palace was used as an occasion for royal ceremony, for example, marriage and coronation ceremony.

Each of the palaces was surrounded by a settlement, lived by the people, hence implying the respect of the people towards their sultan. The settlements were surrounded by two rivers: Sungai Batang Serangan and Sungai Sei Wampu. The market operated since the 1890s, was named as Pajak Ikan Lama, and was located near to Sungai Batang Serangan. The goods were transferred from the river and were sent to Pajak Ikan Lama for sell. The walkability polygon (light yellow colour) shows the preferable area of the people to walk, which was nearby the river and along the settlement area. In front of the palace was also a main street to walk from the settlement at the north to the masjid at the south of Langkat. A madrasah (school) was located near to the masjid. The continuous spaces between the royal enclave and masjid (mosque) gave a sense of intimacy.

\section{Traditional Urban Configuration of Alor Setar}

The history of Kedah is linked to the trade-based routes that had connected South India, insular Malaya, Khmer, and China in the past centuries. An earlier fort named as Kota Kuala Kedah was located facing the coastal area, approximately $10 \mathrm{~km}$ from the urban core of Alor Setar. Several attacks were initiated by Bugis, Acehnese, and Siamese. Thus, the transition was made from a sea trade-based city to inland capital, but the capital was still vulnerable to outside attacks (de Koninck, 1988). The nineteenth Kedah's ruler, Sultan Mohammad Jiwa Zainolabidin (1710-1760), was the founder of Alor Setar. The state mosque, Masjid Zahir, was built in 1912, and the Balai Besar and Balai Nobat were established in 1898.

The monarchy line of Alor Setar was an unbroken line and the oldest monarchy in living history. It is reflected from the seemingly stable pattern of its urban core as the palace, mosque, and other structures such as Balai Nobat are exactly at the same place, although their architecture has been reconstructed. In summation, before Colonisation, the palace, mosque, and Balai Nobat presented a unified urban core.

One of the essential elements of the royal urban core is the Balai Besar, which is located at the Southwest of Istana Kuning (Figure 7). Another element is Balai Nobat, which is opposite to Istana Kuning. Masjid Zahir and padang (open spaces) are located between Balai Besar and Istana Kuning. The public realm includes public buildings such as Balai Besar (an audience hall) and a masjid (mosque). Other features such as the city wall, fencing, and gateways suggest the public's limit of entering.

The commercial areas are located at the urban core, adjacent to the west along the Kedah River and the Anak Bukit River. The padang is located opposite to Balai Besar and Masjid Zahir. The low-density kampung is within 400 metres from the centre of the water transport mode.

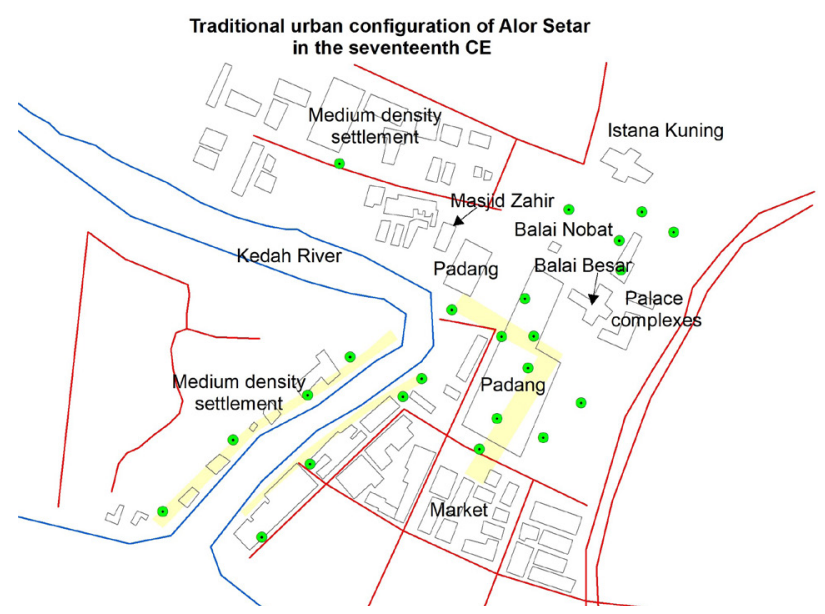

Figure 7. Traditional urban configuration of Alor Setar in the seventeenth CE. 
The royal enclave between the palace and the masjid (mosque) was a continuous integral space with bordering large trees, which created a sense of enclosure and intimacy. In the 1800 s, this configuration (Fig. 8) continued towards the market area by the river side. The population walking itinerary (light yellow areas) was along the shaded pathway river. The walking itinerary shows connections between the palace and the mosque and between the back of the mosque and Tanjung Chali along the riverfront. People used to walk or boat down the mosque towards the corner where the original market was located.

\section{Traditional Urban Configuration of Kota Lama Kanan, Kuala Kangsar}

Kuala Kangsar is the royal urban core of Perak since the reign of Sultan Mansur Shah 1, the son of the last sultan of Melaka, Sultan Mahmud Shah. Unlike other large urban cores in Perak, Kuala Kangsar is essentially a Malay urban core. The "original" Malay urban centre was located at the Kota Lama Kanan during the reign of Sultan Mansur Shah from 1549 to 1577 . In 1800s after the Colonial era, the urban cores was relocated at Sri Sayong and changed again to Bukit Chandan, as requested by the resident of Perak.

Figure 8 shows the urban configuration of Kota Lama Kanan. The drawing was done from the interviews that has been conducted to the villagers. The historical public realm was an open public linkage of such recurring components of the key public structures, such as the palace, the mosque, and the open field. The padang (open space) is located in front of Sungai Perak (behind the mosque), and another padang is located in front of the mosque. These areas were

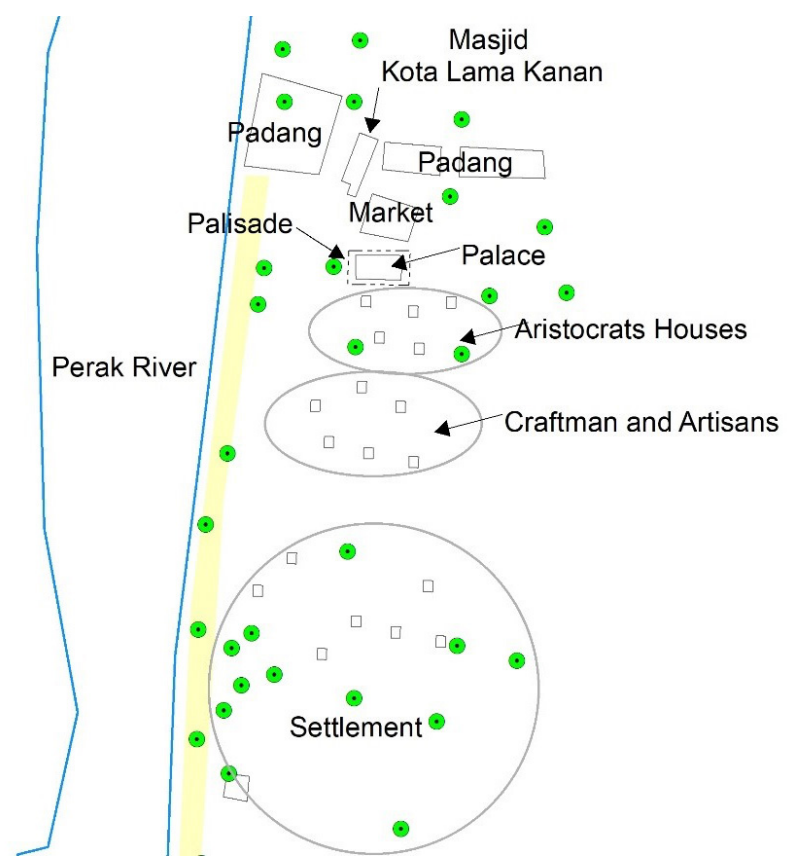

Figure 8. Traditional urban configuration of Kota Lama Kanan in the fifteen $\mathrm{CE}$. used for gathering between the people and the sultan. The palace for Kota Lama Kanan is located near to the mosque, namely Masjid Kota Lama Kanan, and the palace mainly focused on residential purposes. A buluh runcing (palisade) was located around the palace. The padang and market are located in front of the masjid, which implies that the masjid was the centre of public spaces; it was a place for gathering to pray, meeting, and trading activities. The aristocrats houses, craftsmen, and artisans were located just near to the palace thus indicating the importance of their contribution to the royal needs. Lastly, a low-density settlement was found along the river (Sungai Perak). The settlement was also located within the walkability distance, which is less than 400 metres, thus indicating the close relationship between the royal and the people. The trees along the river imply that the people usually worked under the trees for shaded spaces.

\section{Traditional Urban Configuration of Melaka in the Fifteenth Century}

Sultan Megat Iskandar Shah embraced Islam in 1414 and thereafter a significant mosque called Masjid Jamek was built close to the palace. Borbosa (1921) and D'Albuquerque noted the custom, commerce, and development of Melaka as a prosperous and luxurious trading centre and powerful empire, and also the centre of Islamic development in Southeast Asia.

Figure 9 below shows the entrepot, commercial centre, the royal city centre and the neighbourhood, which are indicative of a clustered linear layout strung along both sides of the river bank. The harbour is located on the northern side of the river bank. The entreport was a commercial area located outside the fortified city. The bridge connected the two sides of Upeh and Banda Hilir. The palace is situated at the hilltop hence commanding a view to the harbour and the sea. Masjid Melaka was built at the river bank of the Melaka River. This mosque and palace were the royal administration centre in which people got together for a meeting at the padang, which was located in front of the mosque. The mosque, also called "Masjid Raya," was the main focal point for Muslim social activities. The area of Upeh was a commercial area and location of many traders from Keling, China, and Jawa. The walking itinerary (light yellow colour) of Melaka was from the palace to the mosque across the bridge into the commercial area and down into the harbour.

The port city of Melaka shows that the centrist nature of the riverine and port city reflect a feudal socio-economic system (JahnKassim et al., 2018). The south area was occupied by the elites and foreigners while the north side was the native areas (Wiryomartono, 2011). The urban pattern is organic and clustered, mostly around the main transportation route, river, and around the royal area (where palace located). Such a pattern reflects that the ruler was the centre of the political system. Being at the apex of a system, the Malay city centres around the palatial and public architecture and planning reflects a conventional strict etiquette and social system in which pal- 


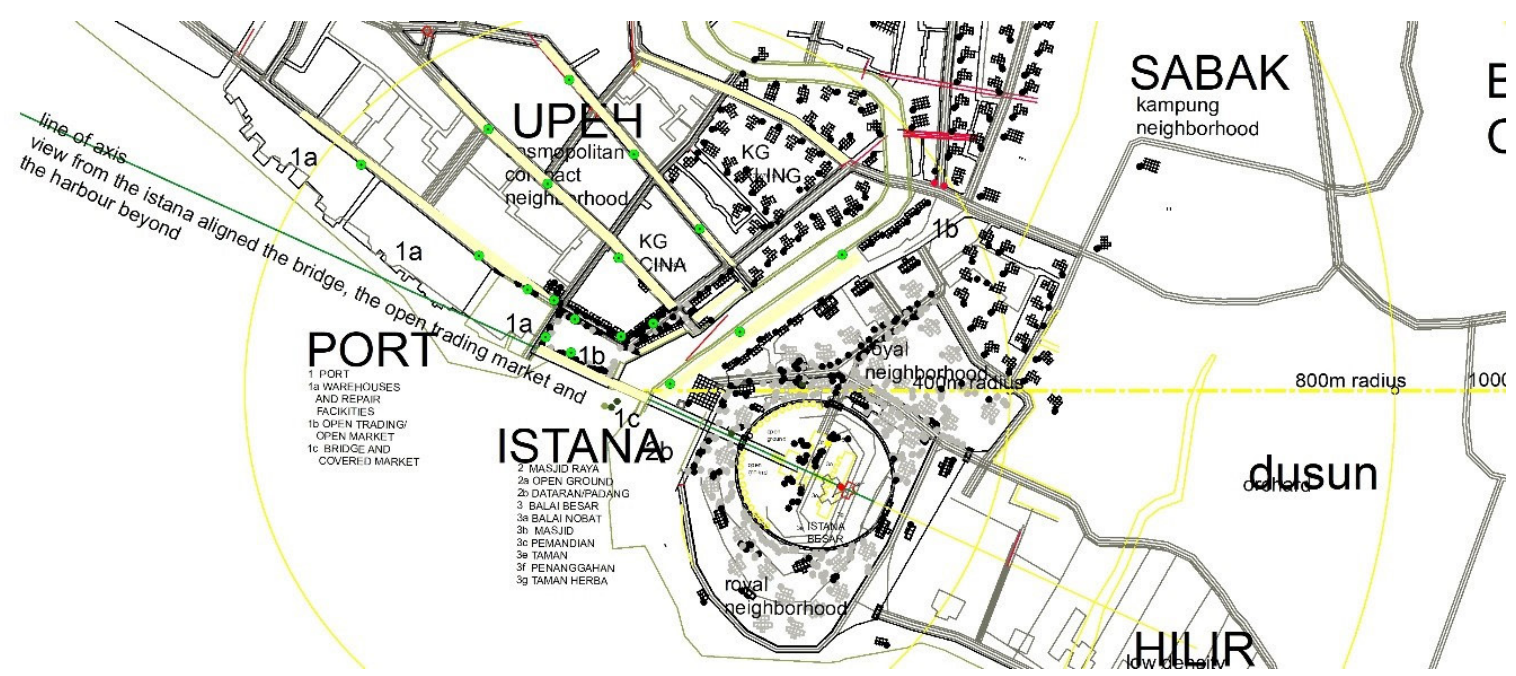

Figure 9. Traditional urban configuration for Melaka in the fifteen CE [(Source: JahnKassim, Ibrahim, Harun, \& Kamaruddin, 2018; walking itinerary (light yellow and trees (dotted green) drawn by the Authors)].

aces played a role of increased public visibility and enhanced public ceremonial impact to the population.

\section{MATRIX ANALYSIS}

The matrix analysis (Table 1) summarises the intimacy of the royal physical elements as well as the distance (in metre) between the historical palaces and their physical elements, such as masjid, padang, settlement, market, and aristocrat houses.

Padang was observed to be located between a palace and a mosque, which explains its importance as a meeting place between the ruler and his people. It was also observed that the padang of urban core is not a perfectly square, which is one of the character of Malay padang. Padang was the symbolic charge of the open green and as a centre of the meeting point. Padang Merdeka in Alor
Setar and Padang Kalumpang in Kota Bharu are examples of a padang being located in front of a Malay sultanate palace (Harun, 2008), and such proximity indicates the value of the residual nature of an open space. The closed distance between a mosque and the palaces indicates the spiritual duality exists between these elements. A mosque was also found to be within a walkability distance to the palace (400 metres). Such proximity indicates that the historical royal urban core followed the Islamic principle of making the mosque a focal point of the capital.

Findings from the analysis indicate that the historical cities were located near to a river. The sloping and hilly areas are still preserved as a place for agricultural activities. The historical capitals appear to conform to the natural landscape in which they were located, even though early technologies have gradually "rearranged" the land

Table 1. Distance between historical palaces and physical elements

\begin{tabular}{|l|l|c|c|c|c|c|}
\hline $\begin{array}{l}\text { Historical Royal } \\
\text { Urban core }\end{array}$ & \multicolumn{1}{|c|}{ Palace } & Masjid & Padang & Settlement & Market & $\begin{array}{c}\text { Aristocrat } \\
\text { houses }\end{array}$ \\
\hline Aceh & Palace Aceh & 100 metre & 50 metre & 400 metre & 20 metre & 50 metre \\
\hline Kuala Kangsar & $\begin{array}{l}\text { Istana Kota } \\
\text { Lama Kanan }\end{array}$ & 60 metre & 30 metre & 220 metre & 20 metre & 20 metre \\
\hline Kuala Selangor & Kota Malawati & 240 metre & 250 metre & 250 metre & 350 metre & NIL \\
\hline Langkat & $\begin{array}{l}\text { Istana Darul } \\
\text { Aman }\end{array}$ & 200 metre & 40 metre & 100 metre & 340 metre & NIL \\
\hline Alor Setar & Istana Kuning & 200 metre & 100 metre & 300 metre & 100 metre & 20 metre \\
\hline Kota Bharu & $\begin{array}{l}\text { Istana Balai } \\
\text { Besar }\end{array}$ & 100 metre & 200 metre & 200 metre & 230 metre & 200 metre \\
\hline Melaka & Istana Melaka & 100 metre & 100 metre & 400 metre & 100 metre & 20 metre \\
\hline $\begin{array}{l}\text { Average } \\
( \pm 10 \text { metre })\end{array}$ & - & 170 metre & 130 metre & 310 metre & 195 metre & 60 metre \\
\hline
\end{tabular}


to suit the evolving human purposes. Activities such as trades, tax, and battles took place near the river. Compared to the current scenario, a road or highway can be seen to assimilate with the river, which was used as the main transportation. A market was located close to the river to ensure that trades were transferable in and out from the area. The marketplace was where trade and commerce took place. Today, the markets or commercial spaces are located close to the main transportation system (road or highway).

Table 2. The distance between Padang and the River, and between Masjid and the Settlement

\begin{tabular}{|l|c|c|}
\hline $\begin{array}{c}\text { Historical Royal } \\
\text { Urban core }\end{array}$ & $\begin{array}{c}\text { Padang to the River } \\
\text { (main river) }\end{array}$ & $\begin{array}{c}\text { Masjid to the } \\
\text { Settlement }\end{array}$ \\
\hline Aceh & 50 metre & 400 metre \\
\hline Kuala Kangsar & 170 metre & 400 metre \\
\hline Kuala Selangor & 110 metre & 400 metre \\
\hline Langkat & 320 metre & 200 metre \\
\hline Alor Setar & 400 metre & 300 metre \\
\hline Melaka & 200 metre & 400 metre \\
\hline Kota Bharu & 120 metre & 400 metre \\
\hline $\begin{array}{l}\text { Average }( \pm 10 \\
\text { metre) }\end{array}$ & 200 metre & 400 metre \\
\hline
\end{tabular}

Further analysis (Table 2) shows the distance between the settlement and the padang, river, and masjid (Table 2). To simplify the analysis, the measurement focused only on the main padang used as a meeting point and the nearest settlement as shown in the respective urban configuration. All the components, including the padang to the river and masjid to the settlement, were found to be within the walkability distance.

Each of the Malay states appeared to have its own kota or fortified urban core as a symbol of political autonomy and from which the ruler and his chiefs exercised their control of the rural hinterland. Several urban cores were relocated due to massive attacks by other powers, such as Kuala Kangsar and Langkat. These urban cores were built in the hinterland, perhaps due to the repeated attacks from Aceh forces, and made near to the river, probably to protect their royal palaces and capital by selecting their vantage points carefully, as well as to detect the enemy approach from afar. In Kuala Kangsar, the experience of place as well as climatic and natural factors were perceived for their simultaneous impact to be felt socially, spiritually, physically, and environmentally. The same approach is also seen in the Langkat urban core, which surrounds the sultanate area. This area now occupies a region known as Hamparan Perak. The Istana Langkat palace forms the centre of an urban pattern connecting the river and the mosque or the centre of religious worship. These patterns recur repeatedly and reflect the nature of the socio-political and religious uni- ty in various South East Asian sites. The nature of the Nusantara city is that social and economic activities also surround the religious core or the "symbolic charge of the urban centre".

In addition, all these urban cores show the sense of enclosure that can be seen from the masjid and the palace are enclosed between each other. Another element is the trees lining the street that also has given a sense of enclosure. These are the places where public and private spaces are clearly distinguished. These Malay urban cores appeared to imitate between each other.

\section{SIMILARITY ANALYSIS OF THE MALAY FORMS}

The Malay urban forms were analysed in terms of several aspects. The estuary urban cores were found to exhibit almost identical characteristics. The compactness of the urban cores implies the profoundness of intimacy because of the walkability between each of the urban elements. All of the urban cores of the settlements face an open field at the centre, which represents the royal enclaves, followed by other structures, including a mosque and an artisan neighbourhood. The following details were identified:

i. The royal urban core used to be located in the riverine areas. It was easy for them for security control over the water traffic. All of the activities such as trades, tax, and battles occurred in the river areas. In addition, the historical royal urban core is within the walkability distance,

ii. The distance from one to another is less than 400 metres as they rely on foot and elephants as the transportation system, and

iii. The padang located near to the river. It was also closed to the mosque and palace. The padang was a very important public space for feast activities and for holding meetings between the royal and the rakyat. The padang used to be a spatial connection between the public and the administration centre. The mosque was the public space and was close to the palace. Islamic influence is seen in all the case studies where the mosque becomes an important landmark in the royal city areas. In these cities, a mosque serves not only for prayers but also for conducting religious studies and discussions.

iv. The element of nearness to the palace is to serve the sultan. A market was also located close to the river to ensure that trading goods were transferable in and out from a particular area. The markets were places where trade and commerce took place.

v. The settlements were along the riverfronts. The residential areas were within walkability distance to the palace of the sultan, indicating thus the good bonding between the sultan and his people. The river was also important for trading activities. 


\section{DISCUSSION}

This research shows that the common elements of the Malay royal areas are a palace, a padang, a market, and settlements. The clear similarities of the case studies are distinct natural features, rivers, and ridges, and all these features influenced the urban core. One of the key parameters of the notion of intimacy in Malay sites is the closeness between the mosque and the palace. If the palace was the public realm of the Malay world during such time, then the mosque was also part of that realm. Both the palace and the mosque are the infecting parts of the same centre; they carried a spiritual connotation and character. A key reflection of such an intimate and communal character is the closeness between the mosque and the palace, which can be measured by a walkable and visual distance.

The main heart of the centres was often located at the highest point of the settlement, and close to the river. In the case of Aceh and Kota Bahru, the fort was an area that functioned as a place for people to gather and discuss important matters. Inside the fort were a palace for the ruler to live in, a well, and other traditional structures such as balairong penanggahan (a place for a meeting between the ruler and the nobleman) and balai gambang (a place to represent animals). At this juncture, the attributes of the configuration, as experienced by the insiders, can perhaps be argued as embodying all the aspects of a Malay urban character, its forms, and urban grain.

The analysis also showed the existence of intimacy within the urban realm. As Milner (2011) describes: "The Malay rulers reflected the organising principle in the Malay world". Wiryomartono (2014) aptly described Melaka as "probably one of the best examples of Southeast waterfront city with multicultural populations". The finding from the analysis, therefore, is supported by Wiryomartono (2011), who claimed that the earlier urban design was ruptured during the post-colonial era as the relics and artefacts of the royal institutions have been replaced, displaced, transformed, and modified by other forms. Looking at the urban patterns of the case studies, a certain configuration can be said to have emerged, reflecting the intimacy not only between a palace and a mosque but also between other key elements of the urban setting, such as a port and a market. Only the forts were near and contained the palace.

\section{CONCLUSIONS}

This paper analyses the configuration of the royal Malay urban core in seven areas. Each of the royal urban cores comply with the walkability distance, which is less than 400 metres to the physical features studied: palace, masjid, padang, settlement, market and aristocrats houses. This precolonial analysis shows that 'intimacy' did exist, but was ruptured during the Colonial era, as many of these elements was not there anymore. This result also suggests that the traditional character is disappearing due to modernisation. The 'intimacy index' for a Malay city notes the average distance from palace to masjid (170 metres), palace to Padang (130 metre), palace to settlement (310 metres), palace to market (210 metres) and aristocrat houses (60 metres).

\section{ACKNOWLEDGEMENTS}

Thank you for an extensive discussion for our TRGS research groups regarding the subject of this paper. Thanks to the International Islamic University of Malaysia and the Ministry of Higher Education (MOHE) for the research grant "Trans-Disciplinary Research Grant Scheme" (TRGS16-03-002-00002). Authors also would like to sincerely thank all referees for their suggestions to improve the manuscript.

\section{REFERENCES}

Abdul Aziz, Zul Arri and Idid, Syed Z. A. (2010). "The Islamic Malay traditional towns learning through the attributes special emphasis on Johor Bahru, Malaysia". First International Conference for Urban \& Architecture Heritage Countries: Its Role in Culture \& Economic Development, pp. 1-20.

Borden, Iain, Rendell; Jane, Kerr, Joe and Pivaro, Alicia (2001). The Unknown City: Contesting Architecture and Social Space. MIT Press.

de Koninck, Rodolphe (1988). "Alor Setar, the Capital of Kedah : a City to Govern Agriculture". Archipel, 36(1), pp. 147-164.

Dekkers, Wim (2011). "Dwelling, house and home: towards a homeled perspective on dementia care". Medicine, Health Care, and Philosophy, 14(3), pp. 291-300. https://doi.org/10.1007/s11019011-9307-2

Harun, Nor Zalina (2008). Role and fate of Padang in Malaysian historical cities. 5th Great Asian Street Symposium 2008, Singapore pp. 1-13.

Harun, Siti N. and Jalil, Rusamah Abdul (2014). "The History and Characteristics of Malay Early Towns in Peninsular Malaysia". Asian Journal of Humanities and Social Studies, 2(3), pp. 403409. Retrieved from www.ajouronline.com [Accessed 30/January/2019]

Jahn Kassim, P. Shireen; Ibrahim, Ilyani; Harun, Nor Zalina and Kamaruddin, Kamariah (2018). "Ecological Urbanism in the Tropics Studies on the Sustainable Dimensions of Malay Traditional Urban Centers". International Journal of Engineering \& Technology, 7(3.9), pp. 93-99.

Milner, Anthony C. (2011). The Malays. Chichester: Wiley-Blackwell.

Nasir, Abdul Halim and Teh, H. H. (1997). Warisan seni bina Melayu. Bangi: Universiti Kebangsaan Malaysia.

Nasir, Abdul Halim. (1990). Kota-kota Melayu. Percetakan Dewan Bahasa dan Pustaka.

Reid, Anthony and Ito, Takeshi (2016). "A Precious Dutch Map of Aceh, c . 1645". Archipel, 57(2), pp. 191-208.

Smith, Michael E. (2007). "Form and Meaning in the Earliest Cities: A New Approach to Ancient Urban Planning". Journal of Planning History, 6(1), pp. 1-47. https://doi.org/10.1177/1538513206293713

Sunaryo, Rony Gunawan (2013). "Morphological Study of Colonial and Traditional Urban Space in Java : A Comparative Study of Ten Cities". 1st Biennale - International Conference on Indonesian Architecture and Planning Morphological, (December). https://doi.org/10.9744/dimensi.40.2.77-88

Windari, Sri (2017). "Kesultanan Langkat di Sumatera Utara Pada Masa Sultan Abdul Aziz (1827-1927 M)". Jurnal Sejarah Peradaban Islam, 1(1), pp. 29-47.

Winstedt, Richard O. (1934). A History Of Perak. Malayan Branch of the Royal Asiatic Society, Singapore. 
Wiryomartono, Bagoes (2011). "Urbanism in the Malay World: The Origin and Evolution of the Idea, Function, and Institution of Pre-colonial Bandar Melaka". The 5th International Conference of the International Forum on Urbanism (IFoU) 2011 National University of Singapore, Department of Architecture Global Visions: Risks and Opportunities for the Urban Planet, pp. 1-10.
Wiryomartono, Bagoes (2014). "Urbanism, place and culture in the Malay world: The politics of domain from pre-colonial to post colonial era". City, Culture and Society, 4(4), pp. 217-227. https://doi.org/10.1016/j.ccs.2013.05.004

Yahya, A. (1998). The Kampong. The Encyclopedia of Malaysia Architecture, Archipelago Press, Kuala Lumpur, Malaysia. 